PERSPEKTIF, 9 (2) (2020): 433-438,

DOI: https://doi.org/10.31289/perspektif.v9i2.3940

PERSPEKTIF

\title{
Analisis Kepuasan Masyarakat Kota Medan terhadap Tim Gugus Tugas Covid-19
}

\section{Citizens Of Medan's Satisfaction Analysis Task Force Covid-19}

\author{
Sri Rezeki1), Diding Kusnady'), Akhwanul Akmal'3), Indra Surya' ${ }^{2)}$, Josi Farmiati ${ }^{4)}$ \\ \& Supriyanto ${ }^{5} *$
}

1) Program Studi Manajemen, Fakultas Ekonomi, Universitas Negeri Medan, Indonesia

2) Program Studi Teknik Informatika, Politeknik Ganesha Medan, Indonesia

3) Program Studi Administrasi Bisnis, Politeknik LP3I Jakarta, Indonesia

4) Program Studi Administrasi Perkantoran, Politeknik Kutaraja, Indonesia

5) Program Studi Administrasi Bisnis, Politeknik LP3I Medan

Diterima: 23 Juni 2020; Disetujui: 14 Juli 2020; Dipublish: 18 Juli 2020

\begin{abstract}
Abstrak
Indonesia salah satu negara yang terpapar oleh Corona Virus Disease (Covid-19), mendorong pemerintah dengan serius membentuk gugus tugas covid-19. Kota Medan merupakan Ibukota Provinsi Sumatera Utara yang sudah terpapar Corona Virus Disease (Covid-19), pada minggu pertama di bulan Juni sudah terdapat 500-an yang ditangani oleh tim Gugus Tugas. Gugus Tugas dibentuk oleh Pemerintah Provinsi Sumatera Utara sebagai garda terdepan untuk memberikan informasi resmi terkait penyebaran virus ini. Baik atau buruknya kinerja Gugus Tugas dalam menjalankan fungsinya dinilai oleh masyarakat. Salah satu bentuk penilaian masyarakat adalah Indeks Kepuasan Masyarakat. Dalam penentuan indeks kepuasan masyarakat, digunakan dimensi Service Quality yaitu tangible, responsiveness, reliability, assurance dan emphaty. Dimensi Tangible meliputi fasilitas fisik tim gugus tugas, perlengkapan serta personel tim gugus tugas. Dimensi responsiveness meliputi kesigapan tim gugus tugas dalam memberikan informasi kepada masyarakat. Dimensi reliability meliputi kemampuan tim gugus tugas dalam memberikan pelayanan berupa informasi yang real dan akurat. Dimensi assurance meliputi kemampuan tim gugus tugas atas pengetahuan terkait penyebaran covid-19. Dimensi emphaty meliputi sikap empati tim gugus tugas terhadap masyarakat Kota Medan. Berdasarkan hasil penelitian, gugus tugas Provinsi Sumatera Utara dinilai Puas oleh masyarakat Kota Medan.
\end{abstract}

Kata Kunci: Tangible, Responsivenss, Reliability, Assurance, Emphaty, Service Quality.

\begin{abstract}
Indonesia one of the countries exposed by corona virus disease (Covid-19), so the government seriously form task force covid-19. Medan City is the provincial capital of North Sumatra have been exposed to corona virus disease (covid-19) until now starting on a sunday first in june had there are about 500 cases handled by the task force. Is an established by the provincial governments north sumatra to provide us with information in guarding the legal the spread of this virus. It be good or bad the performance of a cluster of a duty in perform this function or assessed by the community. One of the community assessment is a community satisfaction index. In determining community satisfaction index, used the quality and tangible service, responsiveness, reliability, assurance and emphaty. Dimensions tangible facilities team covering physical task force, equipment and personnel the task force. Dimensions responsiveness covering the readiness the task force in inform the community. The reliability covering the ability of the task force in providing services of information real and accurate. Dimensions assurance covering the ability of the task force knowledge related to the spread of covid-19. Dimensions emphaty covering an empathy team task force on the community of the City of Medan. Based on the research done, task force the Province of North Sumatra considered satisfied by the community of the City of Medan.
\end{abstract}

Keywords: Tangible, Responsivenss, Reliability, Assurance, Emphaty, Service Quality.

How to Cite: Rezeki, S., Kusnady, D., Akmal, A., Surya, I. Farmiati, J. \& Supriyanto. (2020). Analisis Kepuasan Masyarakat Kota Medan terhadap Tim Gugus Tugas Covid-19. PERSPEKTIF, 9 (2): 433-438

*Corresponding author: ISSN 2085-0328 (Print)

E-mail: faiziqameira@gmail.com ISSN 2541-5913 (online) 


\section{PENDAHULUAN}

Covid-19 pertama kali ditemukan di Kota Wuhan, China pada akhir tahun 2019. Di Indonesia, kasus konfirmasi positif terus meningkat, termasuk di Kota Medan. Pada saat ini di Kota Medan, (Minggu pertama-Juni 2020) terdapat sekitar 500 kasus positif. Pemerintah Provinsi Sumatera membentuk Tim Gugus Tugas Percepatan Pencegahan Penyebaran Virus Corona dengan tugas yaitu memberikan informasi yang akurat dan komunikasi produktif kepada masyarakat Provinsi Sumatera Utara. Komunikasi memiliki peranan penting dalam membentuk organisasi yang efektif dan efisien (Anggraini et al, 2019). Mencermati kondisi yang berkembang, maka dipandang perlu untuk menilai Indeks Kepuasan Masyarakat berdasarkan metode Service Quality terhadap Tim Gugus Tugas.

Service Quality adalah persepsi pelanggan terhadap suatu pelayanan yang didapatkannya (Ginting, 2005). Caruana (Aryani et al, 2011) berpendapat bahwa service quality mempengaruhi loyalitas pelanggan secara tidak langsung melalui kepuasan. Kualitas pelayanan (service quality) sebagai seberapa jauh perbedaan antara harapan dan kenyataan para pelanggan atas layanan yang mereka terima atau peroleh (Lupiyoadi et al, 2006). Kotler (1995) menyatakan bahwa kualitas layanan merupakan suatu bentuk penilaian konsumen terhadap tingkat layanan yang dipersepsikan (perceived service) dengan tingkat pelayanan yang diharapkan (expected value).

Jasa yang diharapkan dan jasa yang dirasakan memiliki dimensi yang sama. Dimensi ini dinilai sewaktu pelanggan diminta untuk menyatakan jasa yang diharapkan dan jasa yang dirasakan yang diterimanya (Parasuraman et al, 1985). Menurut Parasuraman et al (2002) Dimensi kualitas jasa tersebut meliputi Satu, Bukti Langsung (tangibles), meliputi fasilitas fisik, perlengkapan, tim personel dan sarana komunikasi. Dua, Keandalan (reliability), yaitu kemampuan untuk memberikan pelayanan yang dijanjikan dengan segera, akurat dan memuaskan. Tiga, Daya tanggap (responsivenss), yaitu respon atau kesigapan tim personel dalam membantu masyarakat dan memberikan pelayanan yang cepat dan tanggap yang meliputi kesigapan tim personel dalam melayani masyarakat, kecepatan tim personel dalam menangani transaksi, dan penanganan keluhan masyarakat. Empat, Jaminan (assurance), meliputi kemampuan tim personel atas pengetahuan terhadap penyebaran informasi yang jelas kepada masyarakat, keramahan tim personel, perhatian dan kesopanan dalam memberikan pelayanan, keterampilan dalam memberikan informasi dan kemampuan dalam menentukan kepercayaan masyarakat terhadap gugus tugas. Lima, Empati (Emphaty) yaitu perhatian secara individual secara individual yang diberikan institusi kepada masyarakat, seperti kemudahan untuk menghubungi tim gugus tugas, kemampuan tim gugus tugas untuk berkomunikasi degan masyarakat dan usaha tim gugus tugas untuk memahami keinginan dan kebutuhan masyarakat. Dewi (2016) menyatakan bahwa variabel bukti fisik berpengaruh signifikan terhadap kepuasan pelanggan. Lestari (2014) mengungkapkan bahwa keandalan (reliability) berperan dalam pelayanan. Pratama (2015), menyimpulkan bahwa daya tanggap (responsivenss) berperan terhadap kualitas pelayanan yang diberikan oleh penyedia layanan. Marzolina et al (2010) memberikan pernyataan bahwa variabel jaminan (assurance) memberikan kontribusi tingkat kepuasan pelanggan terhadap kualitas pelayanan. Rachmadi (2015) variabel empati (emphaty) memiliki kontribusi dalam memberikan pelayanan publik.

\section{METODE PENELITIAN}

Jenis penelitian ini adalah penelitian deskriptif yaitu suatu jenis penelitian yang bertujuan untuk mendeskripsikan secara sistematik, fakta dan akurat tentang fakta-fakta dan sifat-sifat suatu objek atau populasi tertentu (Ghozali, 2006). Populasi merupakan sekumpulan orang atau objek yang memiliki kesamaan dalam satu atau beberapa hal dan membentuk masalah pokok dalam suatu riset khusus (Santoso, 2002). Populasi pada penelitian adalah masyarakat Kota Medan yang memberikan tanggapan atas kuesioner yang disebar secara online. Objek penelitian ini adalah segala bentuk pelayanan Tim Gugus Tugas Percepatan Penanganan Covid-19 Provinsi Sumatera Utara dengan Sampel Penelitian 100 orang masyarakat Kota Medan. Penelitian ini juga merupakan penelitian survey yang merupakan bagian dari penelitian deskriptif yaitu penelitian yang dilakukan 
untuk memperoleh fakta-fakta dari gejala yang ada dan mencari keterangan secara faktual untuk mendapatkan kebenaran (Rukajat, 2018). Menurut Kasunic (Yuliansyah, 2016) metode survei meliputi aktivitas berupa (1) proses pengukuran yang melibatkan pengajuan pertanyaan kepada responden, (2) mengumpulkan informasi dari sejumlah kecil orang untuk mewakili dari sejumlah besar orang (sampel penelitian survei)

Variabel penelitian adalah variabel independent dan variabel dependent. Variabel independent pada penelitian ini adalah (1) Persepsi Masyarakat yang didefinisikan bahwa penilaian terhadap bentuk pelayanan tim gugus tugas dan (2) Harapan Masyarakat yang didefinisikan sebagai bentuk pelayanan jasa tim gugus tugas yang diharapkan oleh masyarakat yang dirasakan pantas diterima. Sedangkan variabel dependent penelitian ini adalah bentuk kualitas jasa yang diberikan oleh tim gugus tugas.

Sumber data berupa data primer yang didapat dari kuesioner penelitian sedangkan data sekunder berupa tugas-tugas Tim Gugus Tugas. Penelitian ini dilakukan dengan Metode conceptual model of service quality dengan 5 (lima) dimensi yaitu Tangible, Reliability, Responsiveness, Assurance, dan Empathy. Metode ini dikembangkan oleh Parasuraman et al (1988), metode mengidentifikasikan 5 (lima) gap yang mengakibatkan kegagalan penyampaian jasa. Gap 1 : persepsi Tim Gugus Tugas, yaitu adanya perbedaan penilaian pelayanan menurut masyarakat dan persepsi Tim Gugus Tugas mengenai harapan masyarakat. Kesenjangan ini terjadi karena kurangnya orientasi riset pemasaran, pemanfaatan yang tidak memadai atas penemuan penelitian, kurangnya interaksi antara Tim Gugus Tugas dan masyarakat, komunikasi dari bawah ke atas kurang memadai serta terlalu banyaknya tingkat tim gugus tugas. Dengan kata lain, tim gugus tugas tidak selalu dapat merasakan segala sesuatu yang diinginkan para masyarakat secara cepat. Gap 2 : spesifikasi kualitas, yaitu kesenjangan antara persepsi tim gugus tugas mengenai harapan masyarakat dan spesifikasi-spesifikasi kualitas jasa yang ditetapkan. Kesenjangan ini terjadi antara lain karena tidak memadainya komitmen tim gugus tugas terhadap kualitas jasa, persepsi mengenai ketidaklayakan, tidak memadainya standarisasi tugas dan tidak adanya penyusunan tujuan. Gap 3 : penyampaian jasa, yaitu kesenjangan antara spesifikasi kualitas jasa dan penyerahan jasa (delivery service). Tim gugus tugas mungkin kurang dilatih atau bekerja melampaui batas dan tidak memenuhi standar atau mereka dihadapkan pada standar-standar bertentangan. Gap 4 : komunikasi pemasaran, yaitu kesenjangan yang terjadi antara jasa yang diberikan melalui iklan, humas, dengan penyampaian layanan yang sesungguhnya. Harapan masyarakat dipengaruhi oleh pernyataan-pernyataan yang telah dibuat. Gap 5 : penyampaian jasa, yaitu perbedaan persepsi antara yang dirasakan dengan jasa yang diharapkan oleh masyarakat. Adanya perbedaan antara jasa yang dirasakan dan yang diharapkan masyarakat.

\section{HASIL DAN PEMBAHASAN}

Variabel-variabel Service Quality penelitian ini seperti pada Tabel 1 berikut :

Tabel 1. Variabel - Variabel Servqual

\begin{tabular}{|c|c|}
\hline No & Variabel \\
\hline & Tangible \\
\hline $\mathbf{1}$ & Sarana Informasi dan Komunikasi \\
\hline 2 & Kelengkapan Data \\
\hline 3 & $\begin{array}{l}\text { Penampilan Tim Gugus Tugas } \\
\text { Reliability }\end{array}$ \\
\hline 4 & Kemampuan Berkomunikasi \\
\hline 5 & $\begin{array}{l}\text { Kesesuaian Informasi dengan realita } \\
\text { Lapangan }\end{array}$ \\
\hline & Responsiveness \\
\hline 6 & Pelayanan yang Baik \\
\hline 7 & $\begin{array}{l}\text { Ketepatan Waktu dalam Memberikan } \\
\text { Informasi } \\
\text { Assurance }\end{array}$ \\
\hline 8 & Kesigapan Tim \\
\hline 9 & $\begin{array}{l}\text { Prosedur Pelayanan } \\
\text { Emphaty }\end{array}$ \\
\hline 10 & $\begin{array}{l}\text { Kemampuan Tim dalam } \\
\text { Masyarat untuk Mengajak } \\
\text { Kesehatan }\end{array}$ \\
\hline 11 & Transparansi Informasi \\
\hline
\end{tabular}

Sumber: Hasil Rekapitulasi Kuesioner Terbuka

Uji Validitas dilakukan untuk melakukan pengujian kehandalan kuesioner yang disebar kepada masyarakat Kota Medan terkait variabel-variabel Servqual. Berikut ini adalah uji validitas untuk variabel kinerja Tim Gugus Tugas. Terdapat beberapa tahapan dalam melakukan pengujian validitas, yakni: 
1. Penentuan jumlah responden, pada penelitian ini terdapat 100 orang responden

2. Penentuan Nilai Degree Of Freedom (Df), dengan menggunakan rumus $\mathrm{Df}=-2$. Nilai $\mathrm{Df}=100-2=98$

3. Penentuan Nilai $\alpha$, nilai $\alpha=5 \%$

4. Penentuan nilai $r_{\text {tabel }}$ melalui tabel $\mathrm{r}$ product moment. Melalui tabel $\mathrm{r}$ product moment, nilai $r_{\text {tabel }}$ pada penelitian ini adalah 0,198

\begin{tabular}{lccc}
\multicolumn{3}{c}{$\begin{array}{r}\text { Tabel 2. Uji Validitas } \\
\text { Penanganan Covid-19 (Kinerja) }\end{array}$} \\
\hline $\begin{array}{l}\text { Butir } \\
\text { Pertanyaan }\end{array}$ & rhitung & rtabel & Hasil \\
\hline $\mathbf{1}$ & 0,602 & 0,198 & Valid \\
$\mathbf{2}$ & 0,635 & 0,198 & Valid \\
$\mathbf{3}$ & 0,444 & 0,198 & Valid \\
$\mathbf{4}$ & 0,802 & 0,198 & Valid \\
$\mathbf{5}$ & 0,668 & 0,198 & Valid \\
$\mathbf{6}$ & 0,630 & 0,198 & Valid \\
$\mathbf{7}$ & 0,758 & 0,198 & Valid \\
$\mathbf{8}$ & 0,750 & 0,198 & Valid \\
$\mathbf{9}$ & 0,660 & 0,198 & Valid \\
$\mathbf{1 0}$ & 0,568 & 0,198 & Valid \\
$\mathbf{1 1}$ & 0,870 & 0,198 & Valid \\
\hline
\end{tabular}

Sumber: Hasil Pengolahan Data

Tabel 3. Uji Validitas Variabel Gugus Tugas Penanganan Covid-19 (Harapan)

\begin{tabular}{llll}
\hline $\begin{array}{l}\text { Butir } \\
\text { Pertanyaan }\end{array}$ & rhitung & rtabel & Hasil \\
\hline 1 & 0,450 & 0,198 & Valid \\
2 & 0,468 & 0,198 & Valid \\
3 & 0,582 & 0,198 & Valid \\
4 & 0,420 & 0,198 & Valid \\
5 & 0,823 & 0,198 & Valid \\
6 & 0,480 & 0,198 & Valid \\
7 & 0,675 & 0,198 & Valid \\
8 & 0,719 & 0,198 & Valid \\
9 & 0,671 & 0,198 & Valid \\
10 & 0,409 & 0,198 & Valid \\
11 & 0,517 & 0,198 & Valid \\
\hline
\end{tabular}

Sumber: Hasil Pengolahan Data

Uji validitas untuk variabel harapan Tim Gugus Tugas dapat disajikan secara bertahap. Terdapat tahapan dalam melakukan pengujian validitas, yaitu :

1. Penentuan jumlah Responden. Pada penelitian ini, jumlah responden (n) adalah 100 Orang

2. Penentuan Nilai Degree Of Freedom (Df), dengan menggunakan rumus $\mathrm{Df}=-2$. Nilai $\mathrm{Df}=100-2=98$

3. Penentuan Nilai $\alpha$, nilai $\alpha=5 \%$
4. Penentuan nilai $\mathrm{r}_{\text {tabel }}$ melalui tabel $\mathrm{r}$ product moment. Melalui tabel $\mathrm{r}$ product moment, nilai $r_{\text {tabel }}$ pada penelitian ini adalah 0,198

Berdasarkan hasil perhitungan melalui perangkat lunak pengolah data, diperoleh nilai reliabilitas untuk variabel Gugus Tugas Penanganan Covid-19 sebagai berikut.

Tabel 4. Uji Reliabilitas Variabel Gugus

Tugas Penanganan Covid-19 (Kinerja)

\begin{tabular}{ll}
\hline Reliability Statistics & \\
\hline Cronbach's Alpha & N of Items \\
$\mathbf{0}, 893$ & 11 \\
\hline
\end{tabular}

Sumber: Hasil Pengolahan Data

Berdasarkan tabel 4, butir-butir pertanyaan kuesioner pada variabel Gugus Tugas Penanganan Covid-19 (Kinerja) dinyatakan reliabel karena nilai lebih besar dari 0,6. Nilai ini menggambarkan bahwa butir pertanyaan untuk Kinerja pada kuesioner dinyatakan sahih.

Tabel 5. Uji Reliabilitas Variabel Gugus

Tugas Penanganan Covid-19 (Harapan) Reliability Statistics

\begin{tabular}{ll}
\hline $\begin{array}{l}\text { Cronbach's Alpha } \\
\text { o,829 }\end{array}$ & N of Items \\
\hline
\end{tabular}

Sumber: Hasil Pengolahan Data

Berdasarkan tabel 5, butir-butir pertanyaan kuesioner pada variabel Gugus Tugas Penanganan Covid-19 (Harapan) dinyatakan reliabel karena nilai lebih besar dari 0,6 . Nilai ini menggambarkan bahwa butir pertanyaan untuk harapan pada kuesioner dinyatakan sahih.

Gap (Kesenjangan) Persepsi dan Harapan Variabel Gugus Tugas Covid 19 adalah sebagai berikut:

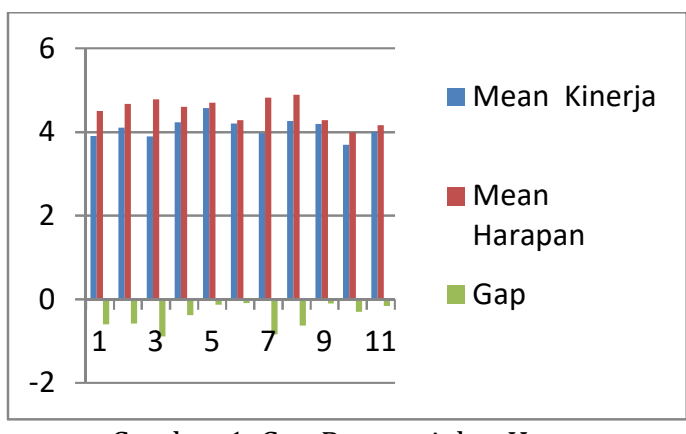

Gambar 1. Gap Persepsi dan Harapan

Pada Gambar 1., diketahui adanya kesenjangan (gap) antara kinerja Gugus Tugas 
Covid 19 Provinsi Sumatera Utara (mean kinerja) dengan dan harapan masyarakat Kota Medan terhadap Gugus Tugas Covid 19 Provinsi Sumatera Utara (mean harapan). Ratarata mean harapan lebih tinggi dibandingkan dengan rata-rata mean kinerja, yang bermakna bahwa masih terdapat kesenjangan antara kinerja Gugus Tugas Covid 19 dengan harapan masyarakat.

Pada tingkat kepuasan masyarakat Kota Medan terhadap Tim Gugus Tugas Covid-19 adalah sebagai berikut :

Tabel 6. Mean Kinerja dan Harapan

\begin{tabular}{lll}
\hline Variabel & Mean Kinerja & Mean Harapan \\
\hline $\mathbf{1}$ & 3,9 & 4,5 \\
$\mathbf{2}$ & 4,1 & 4,67 \\
$\mathbf{3}$ & 3,89 & 4,78 \\
$\mathbf{4}$ & 4,23 & 4,61 \\
$\mathbf{5}$ & 4,57 & 4,7 \\
$\mathbf{6}$ & 4,2 & 4,29 \\
$\mathbf{7}$ & 3,98 & 4,82 \\
$\mathbf{8}$ & 4,27 & 4,9 \\
$\mathbf{9}$ & 4,19 & 4,29 \\
$\mathbf{1 0}$ & 3,7 & 4 \\
$\mathbf{1 1}$ & 4,01 & 4,17 \\
\hline
\end{tabular}

Sumber: Hasil Pengolahan Data

Berdasarkan tabel 6, nilai rata-rata untuk setiap variabel adalah mendekati angka 4, nilai ini menyatakan bahwa secara keseluruhan nilai rata-rata kinerja lebih besar dibandingkan dengan nilai rata-rata harapan, sehingga dapat dinyatakan bahwa Masyarakat Kota Medan Puas terhadap Kinerja Tim Gugus Tugas Percepatan Penanganan Cobid -19.

\section{SIMPULAN}

Penelitian ini dilakukan untuk mengukur kesenjangan antara Harapan Masyarakat Kota Medan dengan Kinerja Tim Gugus Tugas Covid19 Sumatera Utara. Hasil analisis menyatakan adanya kesenjangan (gap) antara persepsi (kinerja) dan harapan masyarakat Kota Medan terhadap Gugus Tugas Covid-19 Provinsi Sumatera Utara. Namun demikian nilai ratarata untuk setiap variabel adalah mendekati angka 4, nilai ini menyatakan bahwa meskipun terdapat kesenjangan Masyarakat Kota Medan menyatakan Puas terhadap Kinerja Tim Gugus Tugas Percepatan Penanganan Covid -19 Provinsi Sumatera Utara.

\section{DAFTAR PUSTAKA}

Anggraini, D., \& Umar, Z. (2019). Pengaruh Komunikasi Terhadap Kinerja Karyawan CV. Bintang Jaya Abadi. Jurnal Ilmiah Maksitek, $4(2)$.

Aryani, D., \& Rosinta, F. (2011). Pengaruh kualitas layanan terhadap kepuasan pelanggan dalam membentuk loyalitas pelanggan. Bisnis \& Birokrasi Journal, 17(2).

Dewi, M., (2016). Pengaruh Kualitas Pelayanan terhadap Kepuasan Pasien Pengguna BPJS pada Rumah Sakit Rehabilitasi Medik Kabupaten Aceh Timur. Jurnal Manajemen Dan Keuangan, Vol 5 (2), 535-544.

Ghozali, I. (2006). Aplikasi Analisis Multivariate dengan Program SPSS. Badan Penerbit Universitas Diponegoro.

Parasuraman, Zeithaml, A.V dan Berry L., (1985). A Conceptual model of Service Quality: Journal of Retailing, Vol. 67: 420-450.

Parasuraman, A., Zeithaml, V., \& Berry, L. (2002). SERVQUAL: A Multiple-item Scale for Measuring Consumer Perceptions of Service Quality. Retailing: Critical Concepts, 64(1), 140.

Ginting, R. (2005). Perbaikan Kualitas jasa Pelayanan Pustaka Dengan Menggunakan Metode Servqual dan Metode Quality Function Deployment di Perpustakaan USU Medan.

Kotler, P. (1995). Manajemen pemasaran analisa, perencanaan, implementasi, dan kegunaan. Edisi Kedelapan. Jakarta: Salemba Empat.

Lestari, K. I. (2014). Kualitas Pelayanan Program Jaminan Kesehatan Daerah (Jamkesda) Di Puskesmas Karang Asam Kecamatan Sungai Kunjang Kota Samarinda, Journal llmu Administrasi Negara, Vol 3 (2), 730-740.

Lupiyoadi, H., \& Hamdani, A. (2006). Manajemen Pemasaran Jasa, Edisi Kedua. Jakarta: Penerbit Salemba Empat, 525.

Marzolina, M., \& Restuti, S. (2010). Analisis Kepuasan Pelanggan (Penumpang Domestik) terhadap Kualitas Pelayanan pada PT. Angkasa Pura H (Persero) Cabang Bandara Sultan Syarif Kasim H Pekanbaru. Jurnal Ekonomi, 18(01).

Pratama, M. H. (2015). Strategi Meningkatkan kualitas pelayanan publik (Studi deskriptif tentang strategi UPTD Pengujian Kendaraan Bermotor Tandes Kota Surabaya dalam meningkatkan kualitas pelayanan pengujian kendaraan bermotor). Kebijakan Dan Manajemen Publik, 3(3), 90-98.

Rachmadi, A. (2015). Kualitas Pelayanan Publik Media Center Di Dinas Komunikasi Dan Informatika Kota Surabaya. Publika, 3(4). 
Sri Rezeki, Diding Kusnady, Akhwanul Akmal, Indra Surya, Josi Farmiati \& Supriyanto, Analisis

Rukajat, A. (2018). Pendekatan Penelitian Kuantitatif: Quantitative Research Approach. Deepublish.

Santoso, S. (2002). Mengolah Data Statistik Menggunakan SPSS.
Yuliansyah, Y. (2016). Meningkatkan Response Rate Pada Penelitian Survey Suatu Study Literature. 